AGRICULTURE AND BIOLOGY JOURNAL OF NORTH AMERICA

ISSN Print: 2151-7517, ISSN Online: 2151-7525, doi:10.5251/abjna.2010.1.5.1069.1075

(C) 2010, ScienceHuß, http://www.scihub.org/ABJNA

\title{
Influence of cobalt on phosphorus uptake, growth and yield of tomato Nadia Gad and Hala Kandil
}

\author{
Plant Nutrition Dep., National Research Centre Dokki, Egypt \\ ABSTRACT
}

\begin{abstract}
A field experiment was carried out in the Research and Production Station, National Research Center, El-Nobaria during the season, 2009 to evaluate the effect of cobalt and different sources of phosphorus fertilizers on the growth, yield quantity and quality of tomato. Treatments can be arranged in descending order as follows: Mono super phosphate (MSP) > Triple super phosphate (TSP) > Rock phosphate (RP). Mono super phosphate (MSP) had superior effect on all growth parameters of tomato shoots and roots yield quantity and quality as well as mineral nutrient constituents of tomato fruits compared with other phosphorus sources. Rock phosphate (RP) treatment gave the lowest values of tomato growth, yield, chemical constituents and mineral composition of tomato fruits. Cobalt addition enhanced all parameters of tomato growth and yield with all sources of phosphorus fertilizers especially with mono super phosphate.
\end{abstract}

Keywords: Cobalt, super phosphate, Rock phosphate, tomato.

\section{INTRODUCTION}

In spite of the absence of evidence for direct role of cobalt in plant metabolism, it is considered to be a beneficial element for higher plants. Tomatoes, the most important vegetable crop in the world, is known to response well to cobalt application Atta-Aly et al., (1991) pointed that supplementing nutrient solution with a low level of cobalt $(0.25 \mathrm{ppm})$ improved growth of tomato plants and enhanced both flowering and fruiting. Boureto et al., (2001) found that, $2.5 \mathrm{ppm}$ cobalt in sand culture was found to be promotive effect on the absorption of $\mathrm{N}, \mathrm{P}$ and $\mathrm{K}$ content in tomato plants. Liu et al., (1995) showed that, growth of onion roots increased with increasing cobalt addition more than shoots. Nadia Gad (2005 a) indicated that, the rate of cobalt at $7.5 \mathrm{ppm}$ significantly increased tomatoes, growth parameters, fruits yield, nutrient concentration as well as total soluble solids, total soluble sugars and L-Ascorbic acid while titratable acidity was decreased. On the other hand, higher cobalt addition in growing media resulted in a negative response.

Phosphorus availability is considered one of the major growth-limiting factors for plants in many natural ecosystems. Plants have developed several adaptive mechanisms to overcome $\mathrm{P}$ stress (Marschner, 1995).

There is indirect evidence of heavy metals buid-up in some agricultural soils due to long-term application of inorganic phosphate fertilizers (Ewa et al. 1999). Trace elements are normally found in phosphate fertilizers Mohammad and Athamneh, (2004).
Even through several types of phosphorus fertilizers are used in crop production, the influence of phosphorus on produce quality is not well understood. Several quality attributes of tomato juice were analyzed in relation to phosphorus supplementation during a three year field study Papadopoulos and Leena Ristimake (2008).

Phosphorus is an essential element in the energy transfer processes; it is needed in the formation of fat, in transformation of starch to sugar, in flowering and fruiting stages. Mono super phosphate has been most widely used a $P$ fertilizer for agricultural purposes in Egypt. Triple super phosphate with $48 \% \mathrm{P}_{2} \mathrm{O}_{5}$ and Rock phosphate with $38 \% \mathrm{P}_{2} \mathrm{O}_{5}$ (Gouda et al. 1990). Supplying vegetable crops with organic and inorganic fertilizers was proved to be very essential for production of higher yield and for improving its quality (Mengal and Kerkby, 1987).

\section{MATERIALS AND METHODS}

Soil analysis: Some physical and chemical soil properties of El-Nubaria Research and Production station, National Research Centre.

Particle size distributions along with soil moisture of the soil sample were determined as described by Blackmore (1972). Soil organic matter, $\mathrm{CaCO}_{3}, \mathrm{pH}$, $\mathrm{EC}$, cations and anions, total $\mathrm{N}$ and available $\mathrm{P}, \mathrm{K}$, $\mathrm{Fe}, \mathrm{Mn}, \mathrm{Zn}$ and $\mathrm{Cu}$ along with total cobalt was determined in Aqua ragia extract, the water soluble cobalt as well as available cobalt (DTPA extractable) being assayed according to Cottenie et al. (1982).

Data of soil analysis was recorded in Table (1) 
Experimental works: On mid February, 2009 seeds of tomato (Lycopersicon esculentums Mill cvs. Super streen) were sown in trays filled with a mixture of sand and peat moss (1:1 volume), trays being kept under greenhouse condition with practicing all agricultural management required for production of tomato seedlings. At the first of April, 2009, the seedlings (at the third truly leaf) were transplanted to El-Nubaria farm under drip irrigation system.

Table (1): Some physical and chemical properties of the used soil at El-Nubaria, Research and Production Station, National Research Centre.

\begin{tabular}{|c|c|c|c|c|c|c|c|c|}
\hline $\begin{array}{l}\text { Soil } \\
\text { pronerty }\end{array}$ & \multicolumn{4}{|c|}{ Particle size distribution \% } & \multicolumn{4}{|c|}{ Soil moisture constant $\%$} \\
\hline \multirow{3}{*}{ Physical } & Sand & Silt & Clay & Texture & Saturation & FC & WP & AW \\
\hline & \multirow{2}{*}{68.7} & \multirow{2}{*}{24.5} & 68 & \multirow{2}{*}{ S L } & \multicolumn{4}{|c|}{$\%$} \\
\hline & & & 6.8 & & 23.0 & 19.2 & 6.1 & 13.1 \\
\hline \multirow{12}{*}{ chemical } & \multicolumn{2}{|c|}{$\mathrm{pH}^{\mathrm{a}}$} & \multicolumn{2}{|c|}{$\begin{array}{c}E C^{b} \\
d S / m\end{array}$} & \multicolumn{2}{|c|}{$\mathrm{CaCO}_{3} \%$} & \multicolumn{2}{|c|}{$\mathrm{OM}^{\mathrm{c}} \%$} \\
\hline & \multicolumn{2}{|c|}{7.8} & \multicolumn{2}{|c|}{0.18} & \multicolumn{2}{|c|}{7.07} & \multicolumn{2}{|c|}{0.16} \\
\hline & \multicolumn{4}{|c|}{ Soluble cations (meq/l) } & \multicolumn{4}{|c|}{ Soluble anions (meq/l) } \\
\hline & $\mathrm{Ca}^{++}$ & $\mathbf{M g}^{++}$ & $\mathrm{K}^{+}$ & $\mathrm{Na}^{+}$ & $\mathrm{CO}_{3}=$ & $\mathrm{HCO}_{3}^{-}$ & $\mathrm{Cl}^{-}$ & SO4 \\
\hline & 3.00 & 2.00 & 0.32 & 2.09 & 0.00 & 1.41 & 0.70 & 5.30 \\
\hline & \multicolumn{2}{|c|}{ Total } & \multicolumn{2}{|c|}{ Available } & \multicolumn{4}{|c|}{ Available micronutrients } \\
\hline & \multicolumn{2}{|c|}{$\mathbf{N}$} & & $\mathrm{K}$ & $\mathrm{Fe}$ & Mn & ZN & $\mathrm{Cu}$ \\
\hline & \multicolumn{4}{|c|}{$\mathrm{mg} / 100 \mathrm{~g}$ soil } & \multicolumn{4}{|c|}{ ppm } \\
\hline & \multirow{4}{*}{\multicolumn{2}{|c|}{15.0}} & \multirow{4}{*}{4} & \multirow{4}{*}{16.0} & 7.8 & 3.3 & 1.86 & 4.0 \\
\hline & & & & & \multicolumn{4}{|c|}{ Cobalt (ppm) } \\
\hline & & & & & Soluble & Avai & & \\
\hline & & & & & 0.49 & 4. & & \\
\hline
\end{tabular}

a: Soil pH was measured in 1:2.5 soil-water suspension, b: EC was measured as $\mathrm{dSm}^{-1}$ in soil paste extract,

S L: sandy loam

The previous experiment was carried out in randomized complete block design with three replicates. The area of each plot $3 \times 2 \mathrm{~m}^{2}$. The experiment contained 6 treatments as follows:-

Received only the recommended doses by Ministry of agricultural of mineral fertilizers i.e $150 \mathrm{Kg} / \mathrm{fed}$ ammonium sulphate and 100 $\mathrm{Kg} / \mathrm{fed}$ potassium sulphate along with three different sources of phosphorus fertilizer:

1- Mono super phosphate at the rate of $200 \mathrm{Kg} / \mathrm{fed}$.

2- $\quad$ Triple super phosphate at the rate of $200 \mathrm{Kg} / \mathrm{fed}$.

3- Rock phosphate at the rate of 200 $\mathrm{Kg} / \mathrm{fed}$.

4- Mono super phosphate at the rate of $200 \mathrm{Kg} / \mathrm{fed}+$ Co (7.5 ppm).

5- $\quad$ Triple super phosphate at the rate of $200 \mathrm{Kg} / \mathrm{fed}+\mathrm{Co}$ (7.5 ppm).

6- Rock phosphate at the rate of 200 $\mathrm{Kg} / \mathrm{fed}+\mathrm{Co}$ (7.5 ppm).

according to Nadia Gad (2005 a).
Measurement plant growth parameters: After 60 days from transplanting (the end of vegetative stage) growth parameters i.e plant height, stem diameter, Number of branches and leaves per plant, leaf area index, root length along with both fresh and dry weights of tomato shoots and roots were determined according to Gabal et al., (1984).

Measurement of yield parameters:-After 105 days from transplanting (the end of fruiting stage), for measuring the fruits number per plant, fruits weight per plant, fruits yield per feddan according to A.O.A.C. (1980).

Measurement tomato fruit quality:-Total Soluble solids, total soluble sugars, L-Ascorbic acid and trtrable acidity (as citric acid) were determined according to A.O.C.S. (1990). Fruits mineral contents namely ( $\mathrm{N}, \mathrm{P}, \mathrm{K}, \mathrm{Fe}, \mathrm{Mn}, \mathrm{Zn}, \mathrm{Cu}$ and $\mathrm{Co}$ ) were determined according to Cottenie et al. (1982).

\section{RESULTS AND DISCUSSION}

Vegetative growth: Data presented in Table (2) outline the response of tomato growth parameters to 
different sources of phosphorus fertilizer with or without cobalt rate of $7.5 \mathrm{ppm}$. Results showed that the superior growth parameters i.e plant height, number of branches and lives number per plant, leaves area index and length were recorded by plants supplied with mono super phosphate. All treatments can be arranged in decreasing order as follows: Mono super phosphate > Triple super phosphate > Rock phosphate. The lowest values of tomato growth parameters were obtained by Rock phosphate.

Mono super phosphate form is more readily in the soil solution and hence to plant than Triple super phosphate. Triple super phosphate form increases the action of acid generated through nitrification of the ammonium ions. In this concern the rock phosphate may be to slowly release and residual values accumulated in the soil (Abdel- Hamid et al. 2003).

It is obvious that cobalt addition caused an enhancement in plant growth parameters with all types of phosphorus fertilizers.

These data are in harmony with those obtained by Nadia Gad (2002) who found that cobalt uptake from soil by either corn and soybean plant increases will the increased phosphorus. Cobalt was shown to promote all growth parameters of tomato plants significantly in vegetative, flowering and fruiting stages (Nadia Gad, 2005 b).

Data in Table (3) illustrate the synergistic effect of mono super phosphate on both fresh and dry weights of tomatoes shoots and roots followed by triple super phosphate while rock phosphate had the lowest effect. Triple super phosphate decreased fresh shoot and root by 12.2 and $13.7 \%$ respectively while rock phosphate decreased fresh shoot and root 24.7 and $29.3 \%$ respectively compared with mono super phosphate. The dry weight decreased by 9.5 and $18.7 \%$ with triple super phosphate while with rock phosphate by 18.7 and $19.5 \%$ respectively. Data also revealed that mono super phosphate increased the dry matter percentage of tomato shoots and roots by 6.3 and $3.29 \%$ compared with triple super phosphate while with Rock phosphate by 12.5 and $11.52 \%$. These results add more support to the results reported by Mehala and Shaktawat (2004) who stated that the addition of mono super phosphate had significant increase on the fresh weights and dry weights of maize plants compared with Triple super phosphate and Rock phosphate. However, cobalt increased shoot fresh weight by 13, 10.9 and $12.8 \%$ respectively since root fresh weight increased by $16.4,16.7$ and $10.4 \%$ respectively. On the other hand, the dry weight of shoot increased by $16.7,12.7$ and $11.6 \%$ while roots dry weight increased by 10.4 , 13.3 and $12.2 \%$ respectively.

Cobalt addition increased dry matter percentage of tomato shoots from 28.6, 28.8 and $25.0 \%$ to 29.2 , 27.5 and $26.2 \%$. While of roots increased \% dry matter from $24.3,23.5$ and $21.5 \%$ to $26.0,24.6$ and $23.2 \%$. These data are in harmony with those obtained by Atta-Aly et al., (1991), Nadia Gad (2005 a) and Papadopoulos and Leena Ristimake (2008). They found that cobalt has a positive effect on both fresh and dry weights as well as dry matter percentage of tomato plants. Cobalt increased the rate of photosynthesis per unit leaf area and the levels of auxins and gebberellins. While catalase and peroxidase enzymes activity were significantly reduced cobalt enhanced the rate of catabolism more than the anabolism one.

Tomato fruits quantity and quality:-The data in Table (4) and Fig (1) represent the yield parameters of tomato as affected by different sources of phosphorus fertilizer and cobalt. Both Triple super phosphate and Rock phosphate fertilizers gave fruits yield lower than Mono super phosphate. Mono super phosphate gave the superior tomato fruits quality. It increased the yield by 18.1 and $34.6 \%$ respectively compared with Triple super phosphate and Rock phosphate.

These results reveal, as expected and as mentioned by moustafa et al. (2005) who stated that, available phosphorus supplementation significantly improved the processing quality characteristics in tomato fruits i.e total soluble solids, vitamin C, color, titratable acidity. It is evident that cobalt addition increased tomato yield by 129, 133 and $116 \%$ with Mono super phosphate, Triple super phosphate and Rock phosphate fertilizers alone. These data reveal, as expected and as mentioned by Vinay et al. (1996) and Nadia Gad (2005 b) who stated that cobalt had a significant favorable effect in both number and weight of tomato fruits per plant. 
Agric. Biol. J. N. Am., 2010, 1(5): 1069-1075

Table (2): Effect of different sources of phosphorus fertilizers and cobalt addition on tomato vegetative growth parameters.

\begin{tabular}{|c|c|c|c|c|c|c|}
\hline \multicolumn{7}{|c|}{60 day after transplanting } \\
\hline \multirow{2}{*}{ Type of phosphorous fertilizer } & \multirow{2}{*}{$\begin{array}{l}\text { Plant } \\
\text { Height } \\
\text { (cm) }\end{array}$} & \multirow{2}{*}{$\begin{array}{c}\text { Stem } \\
\text { diameter } \\
(\mathrm{cm})\end{array}$} & Branches & Leaves & \multirow{2}{*}{$\begin{array}{l}\text { Leaves } \\
\text { area } \\
\left(\mathrm{cm}^{2}\right)\end{array}$} & \multirow{2}{*}{$\begin{array}{l}\text { Root } \\
\text { length } \\
(\mathrm{cm})\end{array}$} \\
\hline & & & \multicolumn{2}{|c|}{ No. /plant } & & \\
\hline \multicolumn{7}{|c|}{ Without cobalt } \\
\hline Mono super phosphate & 134 & 0.8 & 8 & 17 & 287 & 36.2 \\
\hline Triple super phosphate & 122 & 0.7 & 6 & 14 & 242 & 30.3 \\
\hline Rock phosphate & 106 & 0.5 & 4 & 12 & 215 & 24.4 \\
\hline LSD 5\% & 4.75 & 0.11 & 1.15 & 1.63 & 2.28 & 0.38 \\
\hline \multicolumn{7}{|c|}{ With cobalt $(7.5 \mathrm{ppm})$} \\
\hline Mono super phosphate & 161 & 0.9 & 10 & 21 & 356 & 42.1 \\
\hline Triple super phosphate & 143 & 0.8 & 8 & 18 & 309 & 37.3 \\
\hline Rock phosphate & 126 & 0.6 & 6 & 14 & 276 & 30.2 \\
\hline LSD 5\% & 3.98 & 0.16 & 1.63 & 1.68 & 3.23 & 0.63 \\
\hline LSD of interaction at $5 \%$ & 5.34 & 0.18 & 1.92 & 1.89 & 4.18 & 0.98 \\
\hline
\end{tabular}

Table (3): Effect of different sources of phosphorus fertilizers and cobalt addition on fresh and dry weights along with dry matter percentage of tomato plants after $\mathbf{6 0}$ day from transplanting.

\begin{tabular}{|l|c|c|c|c|c|c|}
\hline \multirow{2}{*}{ Type of phosphorous fertilizer } & \multicolumn{2}{c|}{ Fresh weight (gm) } & \multicolumn{2}{c|}{ Dry weight (gm) } & \multicolumn{2}{c|}{ Dry matter (\%) } \\
\cline { 2 - 7 } & Shoot & Root & Shoot & Root & Shoot & Root \\
\hline \multicolumn{7}{|c|}{ Without cobalt } \\
\hline Mono super phosphate & 391 & 59.2 & 112.0 & 14.4 & 28.6 & 24.3 \\
\hline Triple super phosphate & 345 & 48.0 & 92.3 & 11.3 & 26.8 & 23.5 \\
\hline Rock phosphate & 321 & 41.9 & 83.0 & 9.0 & 25.0 & 21.5 \\
\hline LSD 5\% & 5.20 & 0.74 & 0.75 & 0.47 & 0.59 & 0.50 \\
\hline Mono super phosphate & 442 & 68.9 & 129.0 & 15.4 & 29.2 & 26.0 \\
\hline Triple super phosphate & 378 & 55.8 & 104.0 & 14.6 & 27.5 & 24.6 \\
\hline Rock phosphate & 354 & 47.7 & 92.6 & 13.7 & 26.2 & 23.2 \\
\hline LSD 5\% & 4.78 & 0.41 & 1.01 & 0.34 & 0.57 & 0.62 \\
\hline LSD of interaction at 5\% & 6.38 & 0.99 & 1.45 & 0.87 & 1.01 & 0.95 \\
\hline
\end{tabular}

Table (4): Effect of different sources of phosphorus fertilizers and cobalt addition on flowering and fruits yield of tomatoes.

\begin{tabular}{|c|c|c|c|c|c|}
\hline \multicolumn{6}{|c|}{60 day after transplanting } \\
\hline \multirow{2}{*}{ Type of phosphorous fertilizer } & Flowers & Fruits & \multirow{2}{*}{$\begin{array}{c}\text { Fruits weight } \\
\text { (gm/plant) }\end{array}$} & \multicolumn{2}{|c|}{ Fruits yield } \\
\hline & \multicolumn{2}{|c|}{ No./ plant } & & Ton/fed & Relative \% \\
\hline \multicolumn{6}{|c|}{ Without cobalt } \\
\hline Mono super phosphate & 125 & 38 & 1412 & 12.3 & 100 \\
\hline Triple super phosphate & 114 & 32 & 1260 & 10.08 & -18.1 \\
\hline Rock phosphate & 106 & 29 & 888 & 7.95 & -34.6 \\
\hline LSD 5\% & 3.64 & 2.17 & 10.33 & - & - \\
\hline \multicolumn{6}{|c|}{ With cobalt $(7.5 \mathrm{ppm})$} \\
\hline Mono super phosphate & 134 & 46 & 1856 & 15.85 & 129 \\
\hline Triple super phosphate & 128 & 40 & 1670 & 13.36 & 133 \\
\hline Rock phosphate & 114 & 37 & 1042 & 9.22 & 116 \\
\hline LSD 5\% & 2.57 & 2.32 & 6.75 & - & - \\
\hline LSD of interaction at $5 \%$ & 4.59 & 2.78 & 11.69 & - & - \\
\hline
\end{tabular}




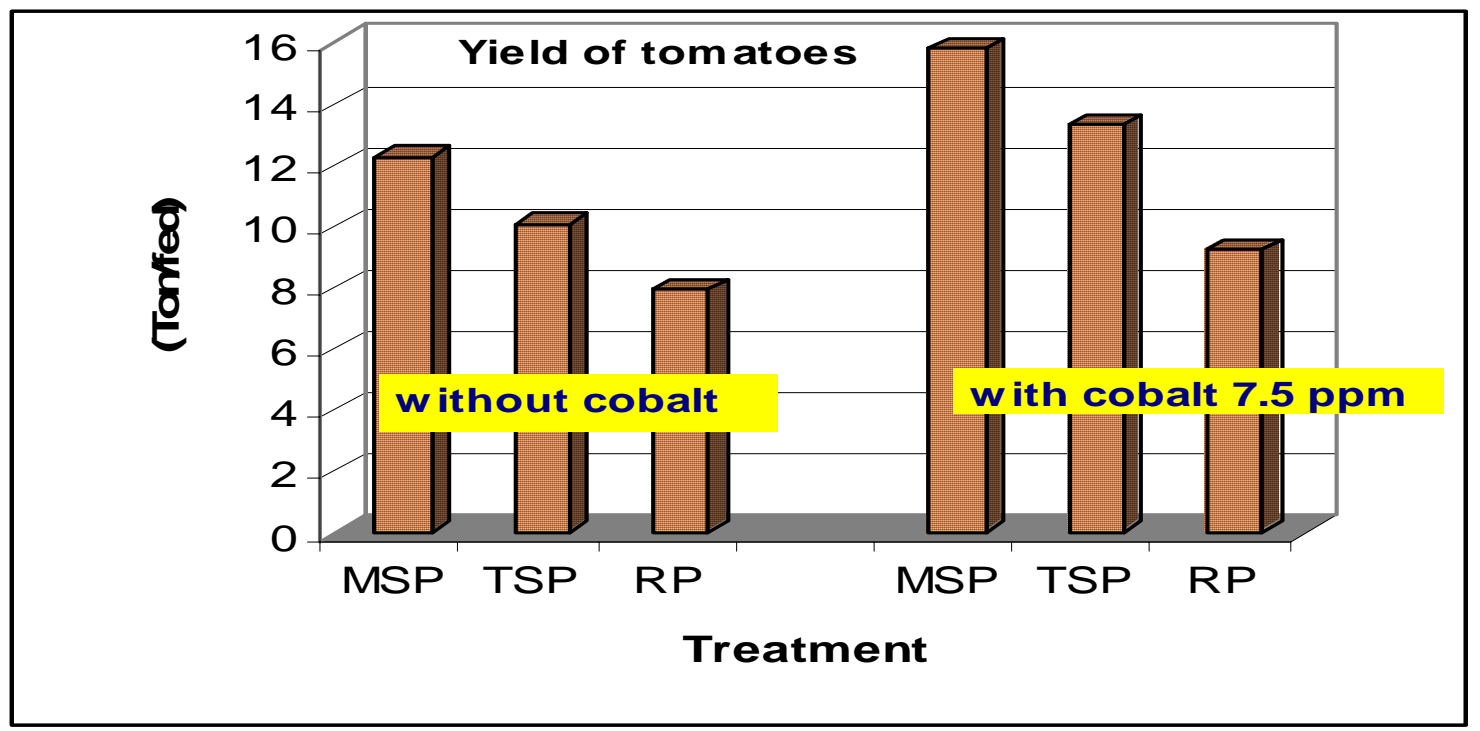

Fig 1. Effect of different sources of phosphorus fertilizers and cobalt addition on fruits yield of tomatoes.

Data presented in Table (5) indicated the positive effect of Mono super phosphate on tomato fruits chemical constituents i.e total soluble solids, total soluble sugars, total protein and vitamin c followed by triple super phosphate while Rock phosphate gave the lowest values. The Titratable acidity was not affected by any of the fertilizer used.

Data also indicated that cobalt addition gave the highest figures of all chemical constituents as quality parameters of tomato fruits. Cobalt decreased the titratable acidity with all sources of phosphorus fertilizers. It should be mentioned that increasing titratable acidity values lower fruits quality. These results agreement with Nadia Gad (2005 b).

Nutritional status of tomato fruits: Data in Table (6) should that Rock phosphate fertilizer gave the lowest values of both macro and micro-nutrients. Mono super phosphate recorded the highest values followed by Triple super phosphate fertilizer.

Data also reflected that the superiority of Mono super phosphate may be attributed to its rapid solubility of which were more than Triple and Rock phosphate fertilizers. The favourable effect of Mono super phosphate on nutrients content of tomato fruits may be due to the direct effect of this phosphorus from in increasing photosynthesis rate and subsequently $\mathrm{N}$, $\mathrm{P}$ and $\mathrm{K}$ contents. These results coincided with those of Arich (1993). Data also indicated a similar trend to the trace elements i.e $\mathrm{Mn}, \mathrm{Zn}, \mathrm{Cu}$ and Fe. These data agree with Nadia Gad (2002) who stated the beneficial effect of phosphorus levels on the content of $\mathrm{Zn}, \mathrm{Fe}, \mathrm{Mn}$ and $\mathrm{Cu}$ on both corn and soybean plants.

Data also indicated that, the addition of cobalt significantly affected elemental nutrition with all sources of phosphorus fertilizer especially with Mono super phosphate. Data also indicated a similar trend to those of the fresh and dry weights of tomatoes. Cobalt enhanced the content of micronutrients except iron. The reduction rate of $\mathrm{Fe}$ indicates the competition between Fe and Co (Nadia Gad, 2005 a). This may be explained on the basis of results reported by Blaylock et al. (1995). 
Agric. Biol. J. N. Am., 2010, 1(5): 1069-1075

Table (5): Effect of different sources of phosphorus fertilizers and cobalt addition on tomato fruits quality.

\begin{tabular}{|c|c|c|c|c|c|}
\hline \multirow[t]{2}{*}{ Type of phosphorous fertilizer } & $\begin{array}{l}\text { Total soluble } \\
\text { solids }\end{array}$ & $\begin{array}{l}\text { Total soluble } \\
\text { sugars }\end{array}$ & $\begin{array}{l}\text { Total } \\
\text { protein }\end{array}$ & \multirow{2}{*}{$\begin{array}{c}\text { Vitamin C } \\
\text { (mg/100gm } \\
\text { fresh tissue) }\end{array}$} & \multirow{2}{*}{$\begin{array}{c}\text { Titratable acidity } \\
\text { (as citric acid) }\end{array}$} \\
\hline & \multicolumn{3}{|c|}{$(\%)$} & & \\
\hline \multicolumn{6}{|c|}{ Without cobalt } \\
\hline Mono super phosphate & 4.65 & 2.67 & 2.23 & 17.54 & 0.49 \\
\hline Triple super phosphate & 4.41 & 2.51 & 2.08 & 17.19 & 0.49 \\
\hline Rock phosphate & 3.59 & 2.26 & 1.99 & 16.49 & 0.49 \\
\hline LSD 5\% & 0.08 & 0.07 & 0.07 & 0.13 & n.s \\
\hline \multicolumn{6}{|c|}{ With cobalt (7.5 ppm) } \\
\hline Mono super phosphate & 4.86 & 2.88 & 2.88 & 17.90 & 0.46 \\
\hline Triple super phosphate & 4.64 & 2.63 & 2.59 & 17.56 & 0.47 \\
\hline Rock phosphate & 3.90 & 2.39 & 2.48 & 16.68 & 0.47 \\
\hline LSD 5\% & 0.09 & 0.08 & 0.07 & 0.14 & n.s \\
\hline LSD of interaction at $5 \%$ & 0.12 & 0.11 & 0.10 & 0.19 & n.s \\
\hline
\end{tabular}

Table (6): Effect of different sources of phosphorus fertilizers and cobalt addition on nutritional content of tomato fruits.

\begin{tabular}{|l|c|c|c|c|c|c|c|c|c|c|}
\hline \multirow{2}{*}{ Type of phosphorous fertilizer } & \multicolumn{9}{c|}{ Macronutrients (\%) } & \multicolumn{7}{c|}{ Micronutrients (ppm) } & \multicolumn{3}{c|}{ Cobalt (ppm) } \\
\cline { 2 - 11 } & $\mathrm{N}$ & $\mathrm{P}$ & $\mathrm{K}$ & $\mathrm{Mn}$ & $\mathrm{Zn}$ & $\mathrm{Cu}$ & $\mathrm{Fe}$ & \multicolumn{2}{c|}{ Shoots } & Fruits \\
\hline & \multicolumn{1}{|c|}{ Without cobalt } \\
\hline Mono super phosphate & 0.357 & 0.261 & 0.366 & 53.3 & 42.6 & 37.7 & 145 & 0.98 & 0.86 \\
\hline Triple super phosphate & 0.333 & 0.236 & 0.298 & 49.4 & 38.8 & 32.0 & 139 & 0.94 & 0.79 \\
\hline Rock phosphate & 0.320 & 0.211 & 0.256 & 44.5 & 32.6 & 29.2 & 133 & 0.87 & 0.72 \\
\hline LSD 5\% & 0.002 & 0.005 & 0.006 & 0.61 & 0.59 & 0.50 & 3.05 & 0.019 & 0.058 \\
\hline \multicolumn{8}{|c|}{ With cobalt (7.5 ppm) } \\
\hline Mono super phosphate & 0.456 & 0.295 & 0.397 & 55.0 & 45.6 & 40.5 & 142 & 2.77 & 1.67 \\
\hline Triple super phosphate & 0.415 & 0.264 & 0.366 & 52.3 & 41.4 & 35.2 & 135 & 2.51 & 1.44 \\
\hline Rock phosphate & 0.397 & 0.242 & 0.323 & 46.6 & 35.7 & 31.6 & 128 & 2.24 & 1.35 \\
\hline LSD 5\% & 0.004 & 0.004 & 0.007 & 0.41 & 0.47 & 0.52 & 2.57 & 0.017 & 0.048 \\
\hline LSD of interaction at 5\% & 0.006 & 0.008 & 0.009 & 0.93 & 0.89 & 0.74 & 3.87 & 0.047 & 0.092 \\
\hline
\end{tabular}

\section{REFERENCES}

Abdel-Hamid, M.A.; S.I. Abdel-Aal; A. Abdel-Fattah; S.A. Ismaiel and A.S. Taalab (2003). The relative residual effectiveness of superphosphate fertilizers and rock phosphate in Torrip samments. Egypt J. Soil Sci.: 43(1): 35-46.

A.O.A.C. (1980). Official Methods of Analysis of The Association of Official Edition, Washington, D. C.

A.O.C.S. (1990). Official and Tentative Methods of American oil Chemists Society. 35 East wacker Drive. Chicago. Illinois, U.S.A.

Arish, H.M.E. (1993). Nitrogen efficiency by natural inhibitor addition in rice ecosystems. J. Agric. Sci.; Mansoura Univ., 22(5): 1787-1800.

Atta- Aly, M. A; N. G. Shehata and T. M. El-Kobbia, 1991. Effect of cobalt on tomatoplant growth and mineral content. Annals Agric. Sci., Ain Shams Univ., Cairo.36: 617-624.

Blackmore, L.C. (1972). Methods for chemical analysis of soils. Newzealand soil Durean, P.A 2 , Rep. No. 10.
Blaylock, A.D.; T.D. Davis; V.D. Juolly and R.H. Walser (1995). Influence of cobalt and iron on photosynthesis, chlorophyll and nutrient in regreening chlorotic tomatoes and soybeans. J. Plant Nutr. 8: 823- 838.

Boureto, A. E.; M. C. Castro and J. N. Kagawa (2001). Effect of cobalt on sugar beet growth and mineral content. Revistra Brasileira Sementes. 18-63-68.

Cottenie, A.; M. Verloo; L. Kiekens; G. Velgh and R. Camerlynck (1982). Chemical Analysis of Plant and Soil. Lab. Anal. Agrochem. State Univ. Gent, Belgium, 63.

Ewa, IOM.; MOA. Oladipo and LA. Dim (1999). Horizontal and vertical distribution of selected metals in the Kubani river. Nigeria as determined by neutron activation analysis. Comm Soil Sci. Plant Anal. 30:1081-1090.

Gabal, M.R.; I.M. Abd-Allah; F.M. Hass and S. Hassannen (1984). Evaluation of some American tomato cultivars grown for early summer production in Egypt, Annals of Agric. Sci. Moshtohor, 22:487-500. 
Gouda, M.; E.E. Kaoud; K. Matter and M.A. Khamis (1990).Effect of some soil and wayer management practices on groundnut in sandy soils. Egypt J. Soil Sci., 30: 331.

Lui, D.; W.Wang; L. Zhai and W. Jiang (1995). Effect of $\mathrm{Mg} 2+, \mathrm{Co} 2+$ and $\mathrm{Hg} 2+$ on the nucleus in root tip cells of Allium cepa. Bulletin of Enviromenta contamination and toxicology. 55: 779-787.

Marschner, H. (1995). "Mineral Nutrition of Higher Plants." Academic Press, London.

Mehala, H.L and M.S. Shaktawat (2004). Effect of source and levels of phosphorus and FYM on yield attributes, yield and nutrients uptake of maize (Zea mays L.) Annals of Agri. Res., 25(4): 571-576.

Mengel, K. and E.A. Kirkby (1987). Principles of plant nutrition. $4^{\text {th }} \mathrm{Ed}$. International Potash Institute, Basel, Switzerland.

Mohammad, M.J. and B.M. Athamneh (2004). Changes of soil fertility and plant uptake of nutrients and heavy metals in response to sewage sludge application to cakareous soil. J. of Agron., 3(3): 229-236.

Moustafa Cke; AHN. Taehyun; Schofield and Gopinadhan pailyzin (2005). Effects of phosphorus fertilizer supplementation on processing quality and functional food ingredients in tomato. Agricultural and Food Chemistry, (519): 742-751.

Nadia Gad (2002). Uptake of Cobalt and some other trace elements as affected by phosphorous levels and Mycorrhizae inoculation. Egypt. J. Soil Sci., 42,(3) pp. 609-623 (2002).

Nadia Gad (2005 a). Interactive effect of cobalt and salinity on tomato plants I- Growth and mineral composition as affected by cobalt and salinity. Research Journal of Agriculture and Biological Sciences Pakistan. 1 (3): 261-269.

Nadia Gad (2005 b). Effect of cobalt on tomato growth, yield and fruit quality. Egypt.J. Appl. Sci., 20 (4) pp. 260-270.

Papadopoulos and Leena M. Ristimaki (2008). Sources of phosphorous fertigation of tomato and Eggplant. Horticulture Society for Horticulture Science, Login Status.

Vinay, S.; H.B. Singh and V. Singh (1996). Influnce of cobalt and phosphorus on their uptake and growth of clusterbean (Cyamopsis tetragonolaba L.). Indian. J. Plant Physiol. 39: 219-224. 